\title{
Jornalistas, médiuns e mandingueiros: os baixos e falsos espiritismos na confecção partilhada de uma religiosidade
}

Moacir Carvalho*

\section{Resumo}

Pretende-se discutir determinadas relações entre "religiões de possessão" e a imprensa nacional no período republicano. Considerar-se-ão, primordialmente, as categorias de "falso" e "baixo espiritismo", concentrando-se na maneira como elas vinham sendo registradas em alguns jornais, principalmente do Rio de Janeiro e de Salvador. Não se pode esquecer que tais categorias se localizavam no interior de um conjunto de relações de dependência particularmente imbricado. Nele, as definições do religioso e suas práticas adquiriam materialidade enquanto objeto de uma dura contenda. Ora luta, ora negociação, mas sempre um processo em duas mãos de que participavam vários agentes, simultaneamente. Melhor ainda, tais categorias parecem expressar as dificuldades enfrentadas por especialistas religiosos e leigos em definir um espaço legítimo, bem como um vocabulário comum, para se falar e fazer religião em condições concorrenciais e supostamente abertas. Circunstâncias essas possibilitadas, inicialmente, pela modificação da legislação nacional, através da constituição de 1891 e do código penal de 1890. Todavia, circunstâncias as quais não eram determinadas em seus conteúdos particulares pelo campo jurídico.

\section{Palavras-chave}

Baixo espiritismo. Imprensa. Concorrência religiosa.

\section{Abstract}

This paper aims to discuss the relationship between religious possession and national press in the Republican period. The categories "false" and "low spiritism" will be primarily considered, focusing on the way they used to be reported in some newspapers from Rio de

\footnotetext{
* Moacir é Cientista Social pela Universidade Federal da Bahia - UFBA; doutorando do Programa de Pós-graduação em Sociologia da Universidade de Brasília, com apoio do Conselho Nacional de Desenvolvimento Científico e Tecnológico - CNPq via bolsa de estudos; e membro do grupo de pesquisa grupo de pesquisa Cultura, Memória e Desenvolvimento. E-mail: moacir.carvalho@gmail.com.
} 
Janeiro and from Salvador. We cannot forget that these categories were located within a set of particularly interwoven relationships of dependence. In that context, religious settings and their practices acquired materiality as an object of a burdensome dispute. Sometimes there would be a conflict; sometimes there would be a negotiation, and there always would be a twohand process involving multiple agents simultaneously. Moreover, these categories seem to express the difficulties faced by religious experts and lay people in order to define a legitimate space as well as a common vocabulary to speak about and practice a religion in supposedly competitive and open conditions. These circumstances were made possible, initially, by a national law amendment, in the 1891 constitution and in the 1890 Penal Code. Nevertheless, these circumstances content specificities were not determined by law.

\section{Keywords}

Low spiritualism. Press. Religious competition.

\section{Introdução}

Neste artigo serão discutidos os usos das expressões baixo e falso espiritismo, durante as primeiras décadas do século XX. Pretende-se com isso aprofundar o debate sobre determinados processos de trocas em que se entrecruzavam práticas ${ }^{1}$ mágico-religiosas e formas letradas de intervenção e classificação dessas mesmas práticas , principalmente, através dos textos jornalísticos. Considerou-se que os termos "baixo" e "falso" espiritismo, ambos aparentemente formulados entre os finais do século XIX e início do XX, poderiam vir a funcionar como excelentes âncoras analíticas para se pensar tanto as mutações religiosas como a sua integração a outras dimensões da vida no período ${ }^{2}$. Isso, tomando-se as duas cidades aqui tratadas: Rio de Janeiro e Salvador. Assim, pergunta-se: tais designativos poderiam ser considerados como um tipo de síntese simbólica esclarecedora

\footnotetext{
${ }^{1}$ Pretende-se no texto evitar interpretações em que se endossem quaisquer polarizações entre cultura letrada e popular, por exemplo, pois interessarão aqui os entrecruzamentos entre formas expressivas distintas, mas entendidas, ambas, em seus duplos caráteres de simbolização e ação.

${ }^{2}$ Além da imprensa: o campo jurídico, a escola, o campo médico-psiquiátrico e a polícia, entre outros.
} 
das dificuldades e paradoxos vividos por religiosos e jornalistas ${ }^{3}$ em um dado campo de ações parcialmente comuns? Ou melhor, ainda que talvez não se tratasse exatamente de um campo comum, ao menos se poderia falar de uma zona de trocas capaz de abrigar ações entrecruzadas e, por vezes, advindas de origens sociologicamente diversas? Algo que, a despeito das intenções dos vários agentes em contato e individualmente considerados, teria pressionado a confecção de cadeias de codependência e simbolização partilhada entre práticas religiosas e textuais.

Assim, as próprias orientações mágico-religiosas serão aqui consideradas como se dirigindo a um espaço multipolarizado e crescentemente concorrencial, contando com praticantes cada vez mais urbanos, escolarizados e reflexivos. Mas, embora fundamental, não se tratou no período apenas do aumento da oferta dos serviços espirituais, mas, também, oferta e demanda de informações, ambições e dúvidas. Por um lado, é possível que alguns indivíduos daquela época tivessem passado a reconhecer nos textos - não apenas nos periódicos religiosos, mas também nas notícias em geral -, uma fonte que se converteria em critério de julgamento; por outro, os próprios jornais, ao combinarem a necessidade de aumentar tiragens com uma curiosidade crescente pelo esquadrinhamento da vida do "povo" (SODRÉ, 1999), aproximavam suas ações daquelas dos praticantes mágico-religiosos. Geravam-se daí cruzamentos de linhas de força em uma zona compartilhada, mas zona essa que não era nem exatamente religiosa, nem jornalística, mas um enredamento sempre em processo dessas funções ${ }^{4}$.

Para o desenvolvimento do argumento, utilizou-se um conjunto de informações disponíveis na literatura sobre o tema, principalmente as encontradas nos trabalhos de Emerson Giumbelli (1997, 2003, 2008) e Yvonne Maggie (1992). Também foram trabalhados textos de jornais e periódicos constantes nos jornais de Salvador e Rio de Janeiro no período que vai de 1890 a 1940, concentrando-se nos anos 1910 a 1930. O levantamento foi feito

\footnotetext{
${ }^{3}$ Foram os jornais durante a República Velha, ou seja, durante cerca de quatro décadas, a principal fonte escrita para um público amplo a respeito das práticas mágico-religiosas. Curiosamente, se as relações entre direito, medicina, polícia e religião têm sido amplamente exploradas pelos pesquisadores do período, há comparativamente poucos trabalhos voltados para a relação entre jornalistas e religiosidades. O de Ângela Lühning, “'Acabe com este santo que Pedrito vem aí': mito e realidade da perseguição policial ao candomblé baiano entre 1920 e 1942", foi um dos poucos que encontrei nesse sentido.

${ }^{4}$ Acrescente-se a essas a função policial, a qual será tratada apenas tangencialmente nesse texto.
} 
durante um período de aproximadamente dois anos, entre 2012 e 2014, em que foram acessados os seguintes acervos: o do Instituto Histórico Geográfico da Bahia; da biblioteca do Mosteiro de São Bento; o Arquivo Público do Estado da Bahia; o setor de periódicos da Biblioteca Central e a Biblioteca Gregório de Matos; também o acervo da Hemeroteca Digital, disponibilizado pela Biblioteca Nacional em forma digitalizada pela internet. Vale ressaltar que, para a grande maioria dos documentos, fez-se o registro por fotografia, sendo a classificação e análise realizadas em momento posterior.

Considerando-se que, se, por um lado, religiosidades populares inseriamse em um espaço compartilhado, no qual um sentido de público se constituía no país, elas também passavam a ter que responder a questões elaboradas em termos distintos dos seus; já os jornais, por seu lado, iriam, a partir das décadas de 1920-1930, ampliar seu leque de possibilidades, pressionando-se um refinamento prático-discursivo mais bem habilitado a acolher aqueles padrões expressivos populares que não encontravam lugar em um modelo exclusivo liberal. Significa dizer que certo refinamento classificatório ocorrido nos jornais entre a terceira e quarta décadas do século XX teria aberto um leque de gradações mais democratizante, mesmo quando não era explícita essa intenção. Todavia, negociação vital não só para os agentes religiosos populares que se viam na mira de policiais e jornalistas (LÜHNING, 1996; MAGGIE, 1992; NEGRÃO, 1996; SCHWARCS, 1993), mas também processo que encontra homologia nas reorientações vividas pelos próprios jornalistas, os quais passavam a reconhecer como necessários procedimentos de pesquisa e verificação diretas na fonte; ao mesmo tempo, transformação de um campo de forças políticas, no qual o profissional começava a ver-se como narrador de uma diversidade nacional que precisaria incorporar um sentido minimamente negociado ${ }^{5}$ das noções de "povo" e "popular" (BURKE, 2010;

\footnotetext{
${ }^{5}$ Como indica Nelson Werneck Sodré, entre o fim do XIX e início do XX, não só se desenvolveria a grande imprensa em moldes empresariais, colocando para segundo plano o jornal partidário e o escritor boêmio, como surgiriam tecnologias capazes de aumentar as tiragens, baixar o custo, e melhorar a apresentação final. Daí também o surgimento de uma série de revistas e jornais - "Revista da Semana", "O malho", "Fon-Fon", "Kosmos", "Careta", "Tico-Tico" com composições ilustradas mais elaboradas, crescendo também a importância do ofício do ilustrador, com a correspondente diversificação e complexificação das imagens. Enfim, "Não havia o que lastimar, entretanto: Lima Barreto sentia a transformação da imprensa brasileira, verificava o contraste entre aquela fase do jornal de circunstância, arrimado a uma figura de prestígio, e a nova fase da empresa jornalística cada vez mais complexa e cada vez mais inserida na complexidade da estrutura social em mudança, emergindo progressivamente a burguesia. A passagem ao jornalismo de empresa era, entretanto, etapa historicamente necessária: significava avanço; o jornalismo individual é que estava ultrapassado" (SODRÉ, 1999, p.288)
} 
CARVALHO, 25013; SODRÉ, 1999).

Processo que impôs também um sacrifício da parte dos agentes mágicoreligiosos de uma série de instituições secularmente testadas, mas que então se tornavam intoleráveis. Tal direcionamento condenatório por vezes contou com uma atividade de tal forma militante dos jornais das primeiras três ou quatro décadas do século, que soaria quase irracional, para os dias de hoje, o tom persecutório de então. Mais ainda, indivíduos de origem popular passavam a ter seu próprio rosto - literalmente - registrado nas páginas dos jornais de ampla circulação, mas agora colados a significados não só alheios a sua vontade, mas, também, distintos daqueles vigentes no período monárquico precedente. Contexto em que segmentos intermediários da população passavam a apresentar aspirações contra-hegemônicas frente a ideais de mundo considerados - se com razão ou não, não importa - típicos das elites (ELIAS, 1997; MICELI, 1979). Estabelecia-se destarte uma disputa simbólica entre elites letradas pela influência sobre os grupos populares, sendo os dois casos, sob esse aspecto, mais expressivos: o Candomblé baiano e a Umbanda paulista-carioca entre as décadas de 1930-1950, principalmente.

Entretanto, é preciso se dar um passo atrás em relação aos significados amplamente atribuídos aos candomblés, umbandas, macumbas e kardecismos, principalmente após a década de 1940, e procurar em outro lugar o ponto de transição para o sentido mais tipicamente denominacional como atribuído às religiões populares de hoje. Ou seja, procurar identificar o momento originário e anterior à institucionalização de dadas coordenações entre intelectuais e popular, em que ter-se-iam gerado como resultados certa elaboração e fixação dos quadros cosmológicos, cosmogônicos, rituais e doutrinários. Esse intervalo anterior marcaria uma cadeia de acontecimentos imprevistos e não orquestrados ocorridos entre os finais do século XIX e início do XX, considerando-se com isso dois momentos limítrofes: primeiramente o do código penal de 1890 e da Constituição de 1891, e, depois, com a Constituição e código penal da década de 1940. Embora não sendo suficientes para explicar a direção tomada pelos eventos religiosos de então, esses acontecimentos indicam para as inflexões mais nítidas entre as religiosidades populares do século XIX e as típicas do século XX. 


\section{Surgimento noticioso dos termos e as ambiguidades de uma "inquisição" secular}

Fenômenos religiosos não são objetos atemporalmente dados, estando em constante transformação e demonstrando uma impressionante capacidade para se recriar e relacionar com variadíssimos aspectos da vida (ASAD, 2010; EISENSTADT, 1969; HERVIEU-LEGER, 2008; TAYLOR, 2007). Sendo assim, também os padrões e princípios de classificação religiosa não poderiam ser compreendidos como se fossem imunes à mudança. No caso brasileiro, por termos vivido a experiência relativamente recente de formação ou rearranjo de algumas expressões espirituais, a complexidade e os desdobramentos de tais mudanças ainda estão sendo explorados. Principalmente quando são pensadas as religiosidades populares, as quais lutavam por definir um lugar tolerável para si mesmas na primeira metade do século XX. E tentar conquistar o designativo de "religião", ao menos a partir desse período, mas talvez um pouco antes, foi um dos meios encontrados para tanto, dentre os mecanismos civilizatórios à disposição. Talvez por isso faça todo sentido a emersão no período das duas expressões aqui exploradas, uma vez tratar-se de designativos que gravitaram, negativamente, em torno da luta integrativodenominacional realizada, sobretudo, pelos espíritas. Trata-se, no caso, de duas categorias oriundas das tensões e aspirações por humanização vividas pelos praticantes das religiosidades de possessão, então chamados de espíritas, espiritistas ou espiritualistas, como se fossem todos termos intercambiáveis.

Contudo, a exploração aqui proposta partiria justamente de um questionamento mais anterior dos significados do ser espírita, e mesmo dos sentidos dados às práticas de possessão em geral, pois as categorias "baixo" e "falso" espiritismo, enquanto sínteses simbólicas de teor acusatório, só se tornaram plenamente significativas no interior da própria disputa de onde emergiram. Daí que parecem abalar, justamente, a crença naturalizada nas hierarquias denominacionalmente hegemonizadas, ao exporem, principalmente na forma em que apareciam nos jornais da época, a fragilidade e os dramas vividos pelos praticantes em suas lutas desiguais. Enfim, questionamento dos próprios procedimentos classificatórios içados por praticantes mágico-religiosos e intelectuais, para além do espaço intrarreligioso, agentes esses inclinados a acolher o suposto da hierarquia entre denominações/ religiões, e "seitas", sendo que parece ter havido um embaraço intelectual entre os pesquisadores da religião, ao menos a partir 
da década de 1930 até 1970, aproximadamente, ao lidarem com fenômenos pouco afeitos a essa perspectiva denominacional. Como se tal ausência carreasse consigo o perigo da desqualificação do praticante e da prática enquanto objeto digno de estudo. E, em tempos de lutas pela representação do nacional (GONÇALVES, 1996), havia também o perigo de se expor o próprio intelectual enquanto ser inábil na arte do bem distinguir: uma religiosidade autêntica, da inautêntica; um espiritismo falso, do verdadeiro.

Mas, recuando-se um pouco mais, não seria exatamente assim que ambas as expressões apareceriam nos registros iniciais do material pesquisado. "Falso espiritismo", primeira a ser encontrada, referia-se em seu nascedouro mais precisamente a uma qualificação da experiência do médium, e não a um tipo particular de reunião mágico-religiosa. Ou seja, designava alguém que, a despeito de qualquer interesse religioso em particular, poderia produzir embustes ou abusos espetaculares de algum poder espiritual, fosse falso ou real, mas, nesse último caso, instável e incontrolável. E, embora o termo já tivesse uso fora do Brasil, Emerson Giumbelli (2003) sugere que seria justamente a partir da apropriação realizada pela Federação Espírita Brasileira (FEB) que ele se incorporaria não só à linguagem jornalística como, a partir da década de 1920, aproximadamente, passaria a compor o discurso jurídico e pericial. Foi apostando nessa sugestão que tomei tais expressões como fundamentais à compreensão do processo de nomeação no interior da formação das religiosidades populares de possessão, principalmente no que diz respeito aos desdobramentos posteriores que colocariam, ora em aproximação, ora em oposição: Umbanda, Macumba, Candomblé e Kardecismo.

A primeira referência a falso espiritismo encontrada foi em matéria do "Jornal do Brasil", do dia 13 de julho de 1901, o que significa que, provavelmente, ele já viesse sendo utilizado anteriormente. Já baixo espiritismo só apareceria no jornal "A Notícia” de 12 de outubro de 1904, corroborando as fontes consultadas com o fato de que, realmente, o uso de "falso" seria anterior, sendo que ambas as expressões aparecem pela primeira vez em jornais cariocas. No primeiro, de 1901, lê-se matéria que ocupa praticamente meia página sob o título "O Espiritismo: manual científico e popular por J. José Franco, traduzido e anunciado por Carlos de Laet" . Porém, nela ficava exposta mais do que uma incerteza e um espírito relativo

${ }^{6}$ Não a transcrevo aqui por conta da limitação de espaço. 
de abertura em relação aos fenômenos tratados, postura que arrefeceria em polêmicas posteriores, nas quais Laet registraria sua própria perspectiva ${ }^{7}$. Endossa o autor a crença nos fenômenos tratados pelos espíritas como reais, questionando apenas a possibilidade de controle sobre os mesmos por parte de quem quer que fosse. Razão porque se produziriam embustes visando à manutenção das retribuições: prestígio e dinheiro. Não se tratava, portanto, ainda do reconhecimento de qualquer vínculo religioso entre prática e praticante, mas de um dom mais ou menos incomum que se podia testemunhar.

Nesse jogo classificatório vai emergindo uma importante interpolação entre falso e verdadeiro, entre autêntico e inautêntico, em coordenação com as capacidades de julgamento, conhecimento e controle. Fica claro na apresentação do texto tratar-se não de uma religião, mas de qualquer técnica ou procedimento que permita a comunicação entre seres humanos e espíritos. Estava-se no interior da gênese das nomeações, e não havia se definido o espiritismo como religião, sendo que práticas mais ou menos identificadas ao trabalho de Alain Kardec também poderiam ser aqui localizadas (FERNANDES, 2008). Por fim, também está ausente do texto qualquer indicação sobre um grupo social em particular, ou conjunto de práticas e recorte socioeconômico específico. Isso só mudaria com a emersão do termo "baixo espiritismo", quando o significante "baixo" passaria a designar outra categoria de coisas e pessoas, vejamos:

\begin{abstract}
"Os curandeiros mãos santas e os que especulam com o baixo espiritismo continuam a exercer a sua negregada missão. Uns estragam o organismo $e$ matam a veneno os ignorantes que os procuram e os inimigos desses ignorantes; outros arrastam as suas sessões nojentas uma multidão de mulheres que ao fim de pouco tempo entram a sofrer das faculdades mentais. Grande acréscimo de hóspedes no hospício tem sido motivado pelo exercício do baixo espiritismo. O Rio de Janeiro explorado pela superstição e pela falsa prática dos ensinamentos de Allan Kardec. Que faz a polícia? Nada. A polícia é uma corporação de incompetentes e malsinados (grifos nossos)" (O Malho, 25 de março de 1905, p.11).
\end{abstract}

\footnotetext{
${ }^{7}$ Ver: Romeu do Amaral Camargo: "O protestantismo e o espiritismo à luz do evangelho: resposta ao Sr. Dr. Carlos de Laet e ao Sr. professor Revmo. Othoniel Motta”. São Paulo: Irmãos Ferraz, 1928. 360 p.
} 
Já não se estaria falando apenas de uma habilidade qualquer, dispersa aleatoriamente entre indivíduos, mas indica-se, ainda que timidamente, um complexo de fatores entrelaçados perfilando não um código, mas a sua suposta corrupção. Logo em seguida, o termo "falso" seguiria a mesma orientação, sendo que os jornais começariam em certo ponto entre a primeira e a segunda década a formular questões incisivas sobre a experiência religiosa, objetivando-as em notícia, mas produzindo-se classificações que designarei como participantes de um senso comum sociológico. Tipificavam-se práticas populares num conjunto correlacionado de fatores, os quais passavam destarte a expressar polarizações objetivadas no campo social. Isso ocorreria em parte graças ao processo em andamento de criminalização associado à interpretação médico-psiquiátrica do espiritismo, em que serão recorrentes termos como hipnose, histeria, neurastenia, esquizofrenia, sugestão, magnetismo. Surge uma preocupação de generalização do comportamento do oficiante que extrapolaria considerações sobre seus saberes e motivos, dando-se vazão a uma explicação mais coletivizada, mas também que precisava dar conta de que se tratava de um processo em que a crença do oficiante tinha que ser de alguma forma considerada visando-se à produção de categorias classificatórias úteis - nem que fosse como patologia.

Aparecem com isso cinco perigos do curandeirismo: ele seria a causa de problemas mentais; ele intoxicaria as pessoas ao tentar dar soluções que só os médicos poderiam; era fonte de enriquecimento ilícito; suas principais vítimas seriam as mulheres; e, em sendo o oficiante um homem, poderia auferir vantagens sexuais da sua clientela. Diante de tamanha ameaça, jornais de várias partes do país começam a pressionar a polícia, acusando-a de leniência. Enfatizava-se o caráter degradante de uma prática na qual cruzavam-se pobreza, ignorância, exploração, crimes e loucura (FERNANDES, 2008; GIUMBELLI, 1997; SOUZA, 2010); excediam-se assim os parâmetros fornecidos pelo código penal. Daí o qualificativo hierarquizador de "baixo" permitir que a acusação de inautenticidade refluísse - para além das questões técnicas e pessoais do médium - na direção do kardecismo, igualmente jovem e nascido da mesma cepa que a Umbanda. Ou seja, com dificuldades para reivindicar a ancestralidade como componente aurática intangível, como o faria de forma modelar o candomblé baiano pouco depois.

Empunhando o seu ofício como arma de desqualificação, o jornalista acaba por revelar uma circunstância de concorrência inter-religiosa que, a julgar pela quantidade e diversidade de perfis e casos de prisões e invasões policias a casas "suspeitas" registradas nas primeiras décadas, não eram 
pequenas. Por outro lado, se esses mesmos jornais começam a reconhecer a liberdade religiosa como algo imposto - "infelizmente" - pela Constituição, sugerem que alguma coisa deveria ser feita no sentido da produção civilizada da exceção. Mas não deixam de reiterar a linguagem da liberdade como parte de uma realidade tangível. Ou seja, participavam da confecção do mesmo princípio que passaria a guiar posteriormente também as próprias lideranças religiosas mais moralizadoras, empenhadas em separar o joio do trigo, a boa da má prática, magia branca e magia negra, enfim, a Umbanda da Quimbanda e o Candomblé da Macumba.

Mas, nas primeiras décadas, tratava-se de uma operação ainda muito mais frágil e fragmentada, levada a cabo de forma pouco integrada por vários especialistas religiosos ou leigos religiosamente interessados, para que se distinguisse, através de textos, debates e palestras: o falso do verdadeiro, o espiritismo do baixo espiritismo. Todavia, pulverização polemista e discursiva que parecia atender muito melhor ao procedimento típico do jornalista - o qual tinha de produzir uma novidade por dia -, que ao do intelectual especializado, de toda sorte indisponível ou em sua maioria pouco interessado pela religiosidade popular até a década de 1930, aproximadamente. Assim, de fato, próximo aos 1910, uma orientação reprobatória dominaria a linha dos argumentos no Rio de Janeiro e, logo em seguida, no restante do país. Em "O falso espiritismo - Uma casa de dar fortuna - Faça o que lhe digo e será feliz - o amor por 150 \$”, lê-se:

\begin{abstract}
“(...) São uma verdadeira praga nos subúrbios, os centros, que marcados com a seita espírita, ali se tem instalado e que com a sanção das autoridades vão explorando a ingenuidade e a ignorância [...] Nestes centros que tem a sua frente indivíduos sem a menor instrução e sem a menor partícula de cultura intelectual passamse fatos inacreditáveis que a mais das vezes trazem consequências graves e funestas para aqueles ignorantes do mal que praticam, os frequentam, em busca da fortuna e felicidade e em procura da realização que almejam. É nesses antros, em que a perversidade atua com uma intensidade extraordinária, que são tramadas a perda e a desgraça de famílias, a separação de casais outrora felizes e satisfeitos, a desonra de pobres e infelizes criaturas, somente porque, aqueles [os policiais] a quem são entregues a nossa vida e a nossa propriedade encontram-se inativos e desleixados. (grifos nossos)" (A Imprensa, 1 de agosto de 1908).
\end{abstract}

Percebe-se um sentimento de temor em relação ao uso "indevido" das forças espirituais por pessoas, supostamente, despreparadas para tanto, 
sendo que aqui o argumento central de Maggie em "O medo do feitiço" de que os acusadores compartilhavam da crença dos acusados parece se confirmar. Em segundo lugar, como havia sido indicado, falso espiritismo é tratando sinonimicamente a baixo espiritismo, como uma forma geral pejorativa de "seita", as "seitas espíritas", visando-se com isso condenar o caráter pretensamente religioso da prática, em comparação com as experiências "científicas" e de cunho filosófico; paradoxalmente, o mesmo discurso que já vinha há algumas décadas sendo reivindicado também por segmentos espíritas. Em terceiro lugar, a exploração monetária do praticante é condenada como ato ilícito - a velha "exploração da credulidade pública", em conformidade aos artigos 156, 157 e 158 do código penal de 1890; mais claramente no 157. Em quarto, novamente a polícia é demandada para que se protejam os três valores burgueses mais queridos: a vida, a propriedade e a família! Proteção contra as ações maléficas, intencionais ou não, produzidas pelos "manipuladores incautos do sagrado". Tudo acusaria uma atitude paternalista dependente da produção de critérios valorativos que vão além do paternalismo Católico advindo daquela ortodoxia mais ao estilo dos séculos XVIII-XIX.

\section{Feitiços e contrafeitiços: a construção social das distinções}

Estava em andamento uma conjunção de ações que, mesmo possuindo objetivos e fundamentos distintos, acabariam por produzir um campo vocabular comum. Quero com isso dizer que os contextos e ações de fala precisam ser entendidos aqui como parte das ações de cunho religioso, capazes de gerar transformações nos próprios significados da religiosidade que se pretendia descrever. Ou seja, que haveria aqui uma double bind, ou hermenêutica dupla posta em movimento. Por um lado, considero que transformações nos padrões civilizacionais iam sendo crescentemente generalizadas, de modo a que aos praticantes religiosos fossem encaminhados questionamentos absolutamente atípicos, quando em comparação aos padrões precedentes do artesão mágico-religioso e por conta própria remanescente do século XIX (REIS, 2008). Mas, ao descrever e condenar o que seria o universo religioso popular, tanto a polícia e os juristas quanto os jornais acabavam por elaborar um campo comum, no qual se formulavam as intermináveis atividades de legitimação, acusação e contra-acusação. Mutava-se, independentemente 
da veracidade do que era dito sobre as práticas e seus oficiantes, a própria realidade que se pretendia descrever. Com isso, os próprios intelectuais, alguns deles mais ou menos aproximados ou ativamente implicados nas práticas espirituais, passavam a agir, reformular e selecionar aspectos que contradiziam a visão tradicionalmente noticiosa e acusatória que grassava nos jornais de então.

Não se podem esquecer que acusações de feitiços e contrafeitiços são características dos circuitos magicamente densos; parte necessária do jogo linguístico de todo especialista: a velha suspeita da "coisa feita" é o mecanismo que instaura a necessidade de reconhecimento, por parte do indivíduo, da existência de uma causa mágica para algum sofrimento. Advém daí a correspondente necessidade de reparação, só possível mediante a assistência de feiticeiro ainda mais poderoso do que nos causou prejuízo. Como dito, foi disso que Maggie deu-se conta: que a eficácia mágica das práticas dependeria desse fundo comum de crenças e códigos, sendo que o enraizamento de tais crenças e saberes ultrapassaria o universo dos mandingueiros, ou mesmo dos segmentos negros pauperizados. De qualquer forma, não só não se trataria, na maioria das vezes, de uma rivalização propriamente "espiritual", até o início do século XX, como as práticas mágicas em geral gozavam de pouco interesse por parte dos jornais, muitos deles "partidários". Era também ausente ou tímida a explícita campanha de difamação de tais práticas, como ocorreria na virada para a década de 1910, quando começam a aparecer as duas expressões aqui exploradas. O que então estaria em andamento para que se desse a rápida popularização de tais expressões?

Em parte, tratou-se de um movimento multirregulatório mais ampliado de fundo de fato católico. Todavia, algo com fortes raízes, tanto nas dinâmicas civilizadoras mais secularizantes que vinham se impondo desde o século XIX, mas que se aceleravam e modificavam com a República, quanto na crescente influência exercida pelas práticas mediúnicas via espiritismo entre as matrizes afro-brasileiras. Não se pode esquecer que tais práticas já vinham chamando a atenção das elites cariocas desde o século XIX. Portanto, a um só tempo, davam-se a cristianização e o aburguesamento religioso das matrizes africanas, o que colocava a luta contra "O mal" ou "A feitiçaria”, acima da típica rivalização individual entre mandingueiros, em que importava conseguir os serviços do mais poderoso para se conquistar o que se desejava em troca do pagamento apropriado; circunstância pretérita também em que a magia defensiva não gozava em si mesma de um valor superior ao de ataque. Ou seja, no período anterior, seria possível, sem 
maiores constrangimentos, contratar-se um serviço visando prejudicar alguém, ou, mesmo se conseguir algo ilegal, sem se estar propriamente na zona do ilícito. O segredo existia e era componente fundamental desse universo, mas não servia tanto para encobrir a prática ou disposição para o mal em si, e, sim, para se proteger de prováveis contrafeitiços, ou mesmo ações violentas de vingança, principalmente quando a vítima vingativa da coisa feita fosse alguém poderoso, dotado de recursos materiais e mana superior - o que costumava encarecer o preço cobrado pelo serviço.

O movimento denominacional popular, ao depender - conforme se verá mais adiante - do avanço caritativo e das práticas de possessão, mudaria completamente o solo sagrado. Sob o ponto de vista das dinâmicas espirituais, tal movimento, ao repousar no dualismo entre mundos, na divisão corpoespírito, bem como na divisão entre práticas boas e más, trouxe para a batalha, agora propriamente espiritual, uma cosmologia inédita baseada na noção de progresso. Tal cosmologia, ao hierarquizar e questionar o valor intrínseco das demandas mágicas, parecia atender a um duplo desafio da época: o de responder ao apelo às nossas raízes históricas mais profundas, e, ao mesmo tempo, fornecer uma utopia realizável diante das esperanças de um futuro melhor frente aos nossos pecados. Pautava-se, para isso, numa crescente repulsa urbana não só aos atos violentos como também a todo aquele que, não fazendo parte dos contingentes policiais e militares oficiais, buscasse reiteradamente infligir sofrimento a outros seres humanos por quaisquer meios ou motivos, salvo em casos limites de autopreservação. Processo profundamente dependente das dinâmicas de pacificação via Estado, em que se empenhavam agentes seculares, e não apenas algo exclusivamente religioso em seus significados. Tal cosmologia e cosmogonia, importantíssimas para os discursos de legitimação de umbandistas e espíritas, tornavam-se, no pelejar entre as décadas de 1920-1950, muito caras às aspirações por uma autêntica cultura popular nacional. Dela, esperava-se que fosse capaz de não só contemporizar com as distintas realidades simbólico-materiais a que se estava sujeito, como, também, responder pacificamente aos enigmas das desiguais velocidades modernizadoras, ligando-se passado, presente e futuro num único ato.

Mas tudo isso só seria possível se se contasse com o avanço de mecanismos normatizadores e reguladores que pudessem ser reconhecidos como autorizados a dar sua última palavra, autenticando a boa prática e favorecendo o bom praticante. O que dependeu, também, de tornar-se o jornalista alguém mais bem informado e capacitado a distinguir, a agir como fiscalizador 
moral do Estado, e, principalmente, da própria sociedade. Seria assim que alguns jornalistas endossariam a separação que colocava, de um lado, o falso espiritismo, de outro, o verdadeiro, sendo que o termo baixo espiritismo passava a ser cada vez mais utilizado por todos. Muito provavelmente eles o fizeram inspirados, direta ou indiretamente, em formulações produzidas por organizações como a FEB, ou principalmente por ela. Aí um critério de utilidade social de fundo jurídico vai se combinar ao religioso, buscando-se fazer com que a ação policial seja explicitamente discriminatória, separando, ela também, o joio do trigo. Por isso, ambas as expressões passariam a poder se intercambiar facilmente. Justamente porque o desqualificativo racial e classista que predominava em "baixo" estaria também servindo para definir o inautêntico, o falso, no sentido de uma prática popular que corromperia a pureza das intenções e conquistas mais elevadas do espírito.

Por exemplo, o centro espírita recifense "Regeneração" anuncia, em 3/5/1913, uma conferência cujo tema era "O verdadeiro e o falso espiritismo". Já em 4/8/1911, no Jornal do Brasil, o centro espírita carioca "Deus e Amor" tenta fazer a separação, defendendo-se, justamente, da suspeição de que o espiritismo teria sido o causador da loucura de Maria Ferreira Mendes Tourinho, o que levaria ao assassinato do condutor de trem Arthur Damaso Tourinho, seu esposo. Maria Tourinho frequentava a "Sociedade Espírita Filhas de Maria do Nazaré". Centro descrito sete anos antes por Paulo Barreto em sua série "As religiões no Rio", quando o liderava o seu fundador e então falecido Ferraz. O mesmo Ferraz do Andaraí, que aparece inúmeras vezes entre os documentos da década de 1890 trabalhados por Maggie. Daí que, na análise desse caso, crença e práticas mágicas seriam suficientes como evidências causais. Mas não se tratava de qualquer crença, pois lá se lê: "como em tudo, também no espiritismo há o verdadeiro e o falso"; pronuncia-se Bezerra de Menezes através de um médium em favor do amor, tolerância e caridade; faz-se a defesa do Catolicismo; imprecam-se os feiticeiros.

A cidade propiciaria aqui algo que a zona rural não permitia: uma intensa atividade multirregulatória, ainda que sob um pano de fundo de suspeição e perseguição com direções imprevistas: regulação recíproca entre agentes, em que comparações, mimetizações, distinções, reprovações e trocas vão se dando em uma velocidade capaz de influenciar a produção de um sentido de consenso interagências. Coordenação de funções em que as forças policiais assumiam o duplo papel de repressão e integração das práticas. Por isso a importância de se estudar as delegacias de costumes e o que nelas se documentou. Era nelas que os profissionais da segurança cumpriam 
essa embaraçosa atribuição, localizada no interior mesmo da dinâmica civilizadora nacional, de mediar e reprimir. Mas o faziam numa zona borrada na qual lícito e ilícito se cruzavam sem que, nem sempre, se pudesse recortar e agir, rigorosamente, apenas sobre práticas que constituíssem claramente violações do código penal. Isso ao menos até a década de 1960, cruzando-se os três ofícios: o religioso, o policial e o do jornalista.

Por fim, a despeito das intenções dos jornalistas, também estes colaboraram na "montagem" do que reprovavam, pois não só propiciavam que agentes distintos se vissem em uma vitrine aberta, principalmente, mas não apenas, aos que sabiam ler, como exigiam uma autoformulação dos próprios praticantes frente ao que se escrevia. Era tão inédito quanto desconcertante que até mesmo a medicina convencional podia ser seviciada publicamente... pelos espíritas. Assim o fez o centro "Redentor" nas páginas do "A Razão" em 1918, na série "O racionalismo com fatos". Este sairia da defensiva, partindo para o confronto direto e chamando médicos psiquiatras de charlatães diplomados, colocando-os com isso junto aos "falsos espíritas" como causadores ou agravadores dos casos de loucura, atacando, inclusive, nomes como Juliano Moreira e A. Austragésilo.

\section{Religiões de possessão e sua institucionalização: "magia branca" ou comecem seviciando o mandingueiro!?}

Certamente que as religiões de possessão não eram novidade no Brasil. Mas seria somente aí que elas, simultaneamente identificadas e opostas aos médicos convencionais, farmacêuticos e sanitaristas, se colocariam como alternativa excludente às técnicas curativas, às propiciadoras da sorte no amor, vingança, riqueza, ou mesmo às artes divinatórias ${ }^{8}$, demandas em grande parte atendidas pelos "mandingueiros-macumbeiros", oficiantes

\footnotetext{
${ }^{8}$ Se atualmente, como afirma Véronique Boyer, trata-se de uma polarização entre o domínio dos procedimentos iniciáticos e aptidões mediúnicas, o período que vai de 1910 a 1940, mas que pode ser estendido para 1890 a 1950, teria sido também o da polarização entre mediunidade e manipulação mágica e divinatória. O que determinaria a vitória da expansão da modalidade mediúnica sobre os tradicionais mágicos, quanto mais aquela assumia e modificava as funções destes; os quais combinavam as leituras de São Cipriano, catolicismo popular, práticas ameríndias e técnicas africanas em seus ofícios, com pesos variados em função das próprias biografias, gostos, demandas e oportunidades de cada um.
} 
informais e por conta própria, aparentemente pouco afeitos às experiências extático-mediúnicas, e trabalhando normalmente sozinhos ou com assistência diminuta. O fenômeno indicado aqui, embora exija maior exploração, implica um processo de transição em que a própria terapêutica passaria a demandar aptidões corporais distintas, precisando o oficiante estar doravante capacitado a entrar em contato com o mundo espiritual, a ser possuído por ou ascender a ele. Mas isso não era fácil, pois se tratava de uma mudança no habitus mágico-religioso dominante até, provavelmente, 1890 e 1910. Tal transição para um novo habitus também implicava em uma transição técnica, como dito, dependente da prerrogativa cosmológica de uma separação entre dois mundos, e que tinha seu correlativo experiencial na divisão corpo-espírito.

O espiritismo vindo da Europa entrava no terreiro, mas com isso não pode evitar o inevitável: que a macumba sentasse em sua mesa, mesmo que disfarçada. Popularizava-se, assim, a concepção de uma esfera cada vez mais elevada a um patamar superior e em contraposição ao baixo corporal, terreno e material, como condição fundamental da eficácia mágica. Dessa forma, ou os velhos "feiticeiros" migravam em direção à formação de um grupo regular de culto, ou corriam o risco de não encontrar lugar no futuro mercado do sagrado. Ou, simplesmente, iriam evadir gradualmente pela morte ou saída do ramo ${ }^{9}$; e, se assim não o fizessem, se degradariam ainda mais como "mandingueiros mercenários", como eram tomados na época: seres ligados às forças malignas. De fato, nada impedia que, no esforço migratório realizado por determinados agentes, ocorresse que, por um lado, alguns dos significados permanecessem intactos, mudando-se apenas o nome da prática, por exemplo; ou podia ser que alguns velhos oficiantes, ao tentarem se adaptar, acabassem tragados para dentro da narrativa do "falso espiritismo", enquanto agonizavam por dominar aptidões mediúnicas

\footnotetext{
${ }^{9}$ Ironicamente, talvez pela comparação com a visibilidade que ganhava o Candomblé baiano no final da década de 1930 em que passava a ser importante uma defesa da cultura popular, lamentava uma reportagem no carioca O Malho de 18 de maio de 1939: “(...) A 'Macumba' [agora com inicial maiúscula] está morta. Ela, é certo, nunca possuiu 'códigos', mas os seus segredos eram, outrora, transmitidos de pai para filho. Presentemente, as velhas famílias de 'pais de santo' desapareceram e a carreira foi invadida, profanada, prostituída, por toda multidão de aventureiros $e$ aproveitadores que utilizam os processos de baixo espiritismo (grifos nossos)" (O Malho, 18 de maio de 1939). Nessa interpretação era a Macumba, anteriormente perseguida por órgãos do Estado e jornais, que então perdia o status de ramo de aventureiros para o espiritismo numa visão intrarreligiosa.
} 
nem sempre possuídas - ou tendo de atrair médiuns poderosos para a sua influência.

Tal configuração colocou a figura do mandingueiro na linha de tiro de kardecistas, umbandistas, jornalistas, candomblecistas, e até mesmo católicos, sendo que a degradação do significante "Macumba", agora quase exclusivamente identificada à bruxaria tropical e negativamente "africana", seria irreversível. Macumba passa a designar o outro da religião, o mal generalizado, seita frente a qual todos poderiam se redimir, fazendo-se dela uma espécie de ponto de fuga para as religiosidades de possessão. Nesse sentido, por um lado, os termos macumba, baixo e falso espiritismo, independentemente dos significados mais precisos a que se pretendesse referir, indicavam uma espécie de sub-religiosidade - a "seita" - possivelmente homóloga à noção mais recente de subproletariad $o^{10}$, comumente aplicada às formas de vida abaixo das condições mínimas de existência e em geral carentes de reconhecimento público, ou melhor, tendo seu reconhecimento mediante a própria carência, ou pelo temor que suscitariam nos relativamente mais bem abastados. Mas, por outro, "macumba" tornou-se tão degradante que permitiu que as mesmas pessoas susceptíveis à acusação de baixo espiritismo encontrassem nela um polo opositivo inferior.

Processo hierarquizador que no campo religioso só pôde obter sucesso quando se contou com a participação ativa dos subalternos que lutavam por reconhecimento num território escorregadio, fossem eles letrados ou fizessem parte dos grupos mais pauperizados, mas que aspiravam por reverter sua miséria em virtude. O que significava, a todo custo, angariar legitimidade (GIUMBELLI, 1997, 2003, 2008; NEGRÂO, 1996; ORTIZ, 1999) para a sua prática contra as suspeições materializadas no cotidiano, nas ações policiais,

\footnotetext{
${ }^{10}$ A categoria subproletariado foi utilizada por Paul Singer designando aqueles segmentos da classe trabalhadora que oferecem sua força de trabalho sem que, no entanto, haja quem tenha interesse em comprá-la por um valor mínimo suficiente à garantia de sua reprodução. Algo similar ao que Florestan Fernandes identificou entre os segmentos de cor em São Paulo, realidade essa constante na maioria das grandes cidades brasileiras ao longo do século. Disponíveis a esse segmento se encontrariam atividades diversas, mas todas igualmente subvalorizadas: serviços e comércio de miudezas, ofícios informais e por conta própria em geral, trabalhos domésticos, de transporte de fardos, limpeza, vendedores ambulantes etc., definindo-se com isso aquele grupo que Jessé Souza chamou de ralé brasileira, mas que ao final do século XX encontrava-se em franca transformação. Segundo Singer, cerca de $63 \%$ da força de trabalho no Brasil compunhase desse perfil subproletarizado, em geral ainda no ano de 1976; mas, mesmo no período que antecede ao primeiro governo Lula, continuava-se no impressionante patamar dos $50 \%$.
} 
nos textos jornalísticos e nos periódicos religiosos mais puristas.

Ocorre que, se na guinada pró-religião o espiritismo expunha-se ainda mais aos ataques, ao mesmo tempo se definia um lugar possível para ele, fosse umbandista ou kardecista. Daí que a polarização não seria apenas em relação ao baixo espiritismo, mas também ao virtuosismo fundamentalista de orientação filosófico-científica. Em relação ao último se manteria fiel o "Redentor", por exemplo, para o qual kardecismo era sinônimo de falso espiritismo. Mas é justamente por isso, pela multipolarização entre posições móveis e sempre relativas umas às outras, que se pode falar de um movimento de convergência:

Nenhum curador, médium, pai de santo, vidente ou adivinho acha que não existem charlatães, mistificadores a serem perseguidos [...] Os que queriam extirpar a crença nos poderes ocultos e os métodos de cura sem diploma médico acabam usando o mesmo discurso dos que querem ou efetivamente usam esses poderes. (MAGGIE, 1992, p.114)

Ou seja, ainda que diferencialmente, todos pareciam vulneráveis aos ataques alheios. Todavia, tal vulnerabilidade não era um absoluto feito um ponto fixo. Definia-se mais pela particularidade opositiva, comunicando singularmente cada componente do par apenas no interior de uma relação (BOURDIEU, 2004; ELIAS, 1997), relação essa com vários reivindicantes, mas ainda sem uma plataforma mínima de consenso ${ }^{11}$. Tudo seria mais simples se se tratasse de dois blocos organizados em disputa. Mas não se tratava sequer de uma luta entre kardecismo e umbanda, ou simplesmente entre espiritismo e seus detratores, como ocorreria com a polêmica entre as denominações protestantes, por exemplo, contra o Catolicismo, em que, ao unirem-se bandeiras comuns, se poderia fazer supor ${ }^{12}$ haver uma luta entre

\footnotetext{
${ }^{11}$ Algo que só seria possibilitado pela disseminação da prática caritativa somada à hegemonia mais decisiva das práticas extático-mediúnicas, algo que permitiria a Procópio Camargo falar mais tarde, por exemplo, de "contínuo mediúnico".

${ }^{12}$ O padre Bento, por exemplo, em "Catecismo antiespírita" afirmaria em 1918: "O Espiritismo grassa como epidemia funesta por todas as classes sociais do Brasil. É uma calamidade social, mil vezes mais perigosa do que as 10 pragas do Egito! Tem sido, é certo, vigorosamente combatida essa abominável seita, mas não deixou por isso de continuar a seduzir inumeráveis incautos" (BENTO, 1918, p.3).
} 
blocos. Enfim, tratava-se de uma luta em que um "aliado" ocasional poderia parecer ameaça em outro contexto.

$\mathrm{E}$, o que inicialmente pode ter sido confortável àquelas associações que podiam contar com intelectuais e contatos privilegiados com policiais, jornalistas, médicos, advogados e juízes, mostraria seus limites quanto mais as religiosidades se complexificavam e, com isso, nem jornalistas, nem policiais, estavam absolutamente seguros sobre os critérios de julgamento que deveriam doravante utilizar. Talvez essa circunstância tenha demandado este tipo de reportagem ${ }^{13}$ :

"Falando aos habitantes do além túmulo - visitando os 'centros' e observando as 'cavações' e os 'cavadores...': Do Brasil a Bahia é talvez o estado que conta maior nmero de supersticiosos e daí talvez a facilidade com que aqui se conserva como uma tradição crenças disparatadas [...] Estamos porém numa época de evolução social. Atravessamos o século da velocidade, do melindrosismo, do almofadismo, do futurismo, do jazz e do Ba-taclan, que mesmo tendo contra si uma pastoral episcopal, aqui exibiu-se e fez sucesso. Se as saias de roupão foram substituídas pelas saias que mal cobrem os joelhos, se a mulher moderna já não ostenta o recato e já não infunde o respeito da mulher antiga; se o flerte e a 'telegrafia' sem fio nos salões de projeções cinematográficas são inocentes passatempos das Evas modernas, era claro que a religião teria também que sofrer séria e grande metamorfose. O repórter andou veladamente por entre os exploradores do baixo espiritismo $e$ do fetichismo observando aqueles indivíduos que aceitam essa ou aquela crença para tê-las como profissão. A ninguém deveria ser permitido exercer a religião como profissão, porque entre uma e outra, vai grande distância. Vai propagando-se de modo amplo o hábito de fazer da religião meio de vida. (grifos nossos)" (A Capital, $29 \mathrm{de}$ outubro de 1926).

Nessa matéria o espiritismo é tratado não só como inovação, como também se assemelha em muito ao que aconteceria mais acentuadamente no Rio e São Paulo. Um conjunto de transformações no estilo de vida, e que era recebido ambiguamente, marcando-se também as tensões regionais que se entrelaçavam ao problema da composição de uma cultura e unidade

\footnotetext{
${ }^{13}$ Deixaram esparsos, porém valiosos registros, figuras como João do Rio, Benjamim Costallat, Leal de Souza, Pedro Silva, Nóbrega da Cunha, Francisco Guimarães, entre outros
} 
nacionais. E se a virada entre as décadas de 1920-1930 foi de acirrada perseguição, provavelmente a mais violenta de todas, ela também foi aquela em que se condensou num instante a consciência de uma diversidade cada vez mais desafiadora aos planos de unidade.

Não por coincidência, o período que vai de 1924 a 1930 foi marcado por um intenso trabalho de normatização e regulamentação por parte da FEB no Rio de Janeiro, com o intuito de padronizar a relação entre federação e federados através de critérios escritos, públicos e pré-fixados (GIUMBELLI, 2003), o que resultaria em uma acelerada afiliação. Assim, pela matéria anterior transparece um complexo de elementos, no qual o próprio repórter não só identificaria contradições, como expressaria, ele mesmo, opiniões contraditórias. Mas, ao contrário de acusar uma escrita redutora ao mínimo necessário da mandinga, por exemplo, tais contradições começariam a surgir, justamente, por um esforço de desambiguação dos escorregadios baixo e falso espiritismo. Ou seja, tais contradições se constituem e revelam no próprio esforço de categorização do repórter, que queria superar a linguagem mistificadora que o jornalismo dominante das décadas de 19101930 ainda empregaria para descrever as religiosidades populares. Se os religiosos participavam da nomeação das suas práticas, os jornais também o faziam $^{14}$. E ambos, jornais e religiosos, encontravam-se numa época em que a demanda por informações, recursos e reconhecimento ${ }^{15}$ parecia ultrapassar os limites tradicionalmente permitidos ao "povo". Algo muito além da articulação fiscalizadora entre condenação prévia, denúncia e moralização/

\footnotetext{
${ }^{14}$ Macumba se tornava algo bem pior que espiritismo, mas ainda não pior que candomblé. Pode-se perceber isso em "Macumba na Praça 15", o jornalista opta pelo tom galhofeiro: "Eram 10 horas da noite. O povo estava aglomerado próximo ao hotel de França na Praça 15. E do $1^{\circ}$ andar n. 40 daquela praça, saía o cântico dolente do candomblé: 'Eh bumba! Tá no mato tocando macumba! Caxinguelê! Caxinguelê Calunga!'. O Caxinguelê, por si só, já é feio. Imaginem os leitores um caxingulê calunga. $\mathrm{O}$ caxinguelê que ontem nos atraiu na macumba de ontem é assim (...) Na porta da macumba estava o auto particular n. 7740. De quem é esse automóvel? É do Dr. Raul de Farias. O deputado? Sim senhor (...) O chefe da macumba é o seu Meirelles, funcionário da prefeitura. Dizem que é centro espírita. Há, porém, quem afirme que é candomblé” (A Manhã, 28 de agosto de 1926).

${ }^{15}$ Em 9 de setembro de 1928, por exemplo, no Correio Paulistano vê-se anúncio da Livraria Religiosa em que se vendem "pequenas bibliotecas para organização de centros espíritas". Formava-se um mercado editorial baseado numa literatura comum. Desdobrava-se o esforço de sistematização já iniciado nas décadas anteriores, produzindo-se iniciativas voltadas para a constituição de um vocabulário mínimo.
} 
intervenção corretiva, em que, como aponta Emerson Giumbelli, entre outros $^{16}$, o diálogo entre FEB e polícia seria fundamental.

\section{Considerações finais}

Quanto mais o espiritismo aprofundava-se na definição do que ele deveria ser, mais inflexível se tornava, e mais impraticável seria para a polícia e a justiça decidirem sobre questões cada vez mais tidas como exclusivamente religiosas. Contradição que só encontraria solução oficial através da modificação no código penal de 1946, e com a desvinculação entre delegacias de costumes e prática religiosa. Sob o ponto de vista do processo mais longo, com a ascendência dos cultos mediúnicos passaram-se a se redefinir os critérios de validade, de forma que a composição a um só tempo experiencial e expressiva ligada à incorporação de entidades ou espíritos suplantou o velho mandingueiro. Significa dizer que, excluindo-se a intervenção direta sobre o corpo físico do paciente, criava-se uma circunstância distinta daquela para a qual o código penal de 1890, principalmente no artigo 158, tinha sido elaborado, pois os espíritos podiam agir no plano imaterial sem recorrer às beberagens, por exemplo.

Também, não estava prevista a entrada em cena de agentes populares tentandoangariar prestígioatravés de uma prática mediúnica que os segmentos intermediários tentavam monopolizar, ou ao menos dirigir e justificar. Com a imprevista colaboração entre esses segmentos diferencialmente dominados, comprometia-se a reprodução linear de um padrão excludente. Este combinou a liberdade religiosa da Constituição de 1891 com um código nem sempre oficial, mas que encontrava apoio no Código Penal de 1890, bem como em procedimentos hoje considerados, no mínimo, questionáveis, por parte de policiais e jornalistas, e que dividiam o campo entre a boa e a má prática popular.

E é justamente nesse ponto que a noção de caridade (MONTERO, 2006) viria a ter importância como linha divisória entre ciência, filosofia

\footnotetext{
16 "Foram fechados vários centros espíritas onde se verificou não ser o seu intuito a caridade, mas sim o aproveitamento da ignorância dos incautos que os frequentavam. Na concessão de licenças para a organização de centros espirituais foi adotado o critério de estudar e investigar, não só a moralidade, senão também a capacidade intelectual dos seus dirigentes." (Relatório do chefe de polícia de 1928, em WISSENBACH, 2004, p.29).
} 
e religião, da forma como se misturavam no espiritismo. Daí que quase todos os praticantes das religiões de possessão passariam a valorizar a caridade física ou espiritual em forma de "magia branca", e repudiar - ao menos oficialmente - a "magia negra" como parte integrante da verdadeira religião. Mas, como indicado, esse processo não implicava apenas sinalizar, pela moeda do desinteresse caritativo, que não se era "magia negra", mas também criavam-se aí as condições universais para a especificação de um campo mágico-religioso nacional pacificado em suas funções precípuas de monopólico sobre o sagrado imaterial. Tornando-se esfera própria ao passo em que se sinalizava um compromisso público com a contenção das agressões, o que, claro, não significou na prática que o malefício tenha desaparecido das demandas ${ }^{17}$. Mas se tratou de um contexto em que a disposição para seu exercício já não poderia ser verbalizada abertamente, sem o risco de perda da reputação.

Ao mesmo tempo ia ficando clara entre as décadas de 1910-1920, talvez mais precocemente no "Centro Redentor" que na FEB, uma reivindicação doutrinária e organizacional própria que visava a uma cartada política, com o que se esperava conquistar os afagos do poder. Esses grupos, ao defenderem incondicionalmente o respeito aos poderes laicos, o fizeram opondo-se duramente ao Catolicismo. Este sempre comprometido: hoje com Roma, ontem, com a monarquia. Enfim, poderoso inimigo interno da república. Dessa forma, tais grupos opunham-se a determinadas práticas produtoras da exceção que vigorariam na República, sem, contudo, acusar a República em si mesma; opunham-se ao Catolicismo, sem contudo opor-se ao cristianismo, sendo que a própria pressão exercida pelo "Redentor" teria acelerado

\footnotetext{
${ }^{17}$ Exu deixaria de ser apenas o mensageiro, identificando-se às forças do mal. Em outro artigo, argumento não ter se tratado, nem de uma assimilação passiva da identificação entre Diabo e Exu, nem apenas da criação de funções desvinculadas de sua vida pregressa. Ocorreria, ao contrário, uma homologia de funções em que, quanto mais as demandas nacionais por malefício dependiam de entidades espirituais dotadas de personalidade e preferências, mais os poderes se antroporfizavam. Exú, já identificado por cristãos e muçulmanos ao Diabo, tornavase a escolha mais natural para atender a tais demandas, pois a quem ou o que se recorreria para fazer o mal, se o antigo mandingueiro estava desaparecendo ou perdendo reputação? E, embora ciente de que práticas de possessão não seriam novidade no Brasil, estou convencido de que elas não foram, nas décadas anteriores ao 1890-1900, o padrão dominante. Não adviriam daí determinadas ambiguidades da entidade Exu ao longo do século, em sua identificação, ora com um protetor e cuidador prestativo, ora como ameaça e desordem demoníaca? Algo provavelmente mais dinâmico e presente que a persistência de um traço ou mácula herdada de alguma origem mítica ou degradação cristã, ainda que elas tenham sua contribuição para a composição atual do personagem.
} 
simultaneamente a consolidação de um conjunto de canais de comunicação e aparelhos regulatórios na $\mathrm{FEB}^{18}$. Seria nessa dinâmica entre batalha e negociação, tanto inter-religiosa como em relação ao Estado e, para o nosso caso, aos jornalistas, que se pavimentaria um caminho realizável aos novos grupos denominacionalmente orientados. Esses foram responsáveis pela turbulência, provavelmente a mais significativa, vivida pelo campo religioso nacional, desde o abrandamento do processo de conversão massiva dos autóctones e africanos escravizados, ocorrida no período colonial.

Como indicado, ao mesmo tempo em que a relação entre organizações espíritas e Estado transformava-se, a partir de 1946, ficariam os cultos espíritas em geral definitivamente fora do raio de ação desse Estado. Nesse processo participaram e foram favorecidos também a Umbanda e o Candomblé. Mas também aqui a insuficiência do campo jurídico como fator exclusivo ou decisivo a ser considerado se explicita, pois, curiosamente, na Bahia, os oficiantes do Candomblé precisariam, até a década de 1976, obter autorização junto à delegacia de jogos e costumes para poderem funcionar. Seja como for, não mais se tratava de perseguir objetivos idênticos, e sim conseguir atuar através de uma especialização e coordenação de funções, as quais poderiam ser até mesmo complementares, ainda que se perseguissem fins distintos:

Quando observamos o ano de 1945, o que temos nãoé propriamente uma concordância quanto aos critérios de legitimidade para as práticas espíritas. As portarias policiais pautam-se por parâmetros que não são absolutamente os mesmos que os adotados pela Federação Espírita Brasileira - e ambos são ainda distintos daqueles consagrados pelo Código Penal de 1942 na sua parte relativa aos crimes de exercício legal da medicina, charlatanismo e curandeirismo. O que ocorre é uma convergência entre o modo como as autoridades policiais definem seu papel nesse campo de agentes e práticas e as pretensões organizativas e normativas da FEB - de tal forma que se espera dela algo que ela mesma se sente capaz de fazer, ou seja, o cumprimento de funções que são a um só tempo políticas e religiosas. (GIUMBELLI, 2003, p.17)

Tudo isso foi devastador para a macumba carioca, feita alteridade frente aos candomblés baianos, Umbanda e Espiritismo, os quais se organizariam no

\footnotetext{
${ }^{18}$ Desde os 1880 (COSTA, 2002, p. 41) que espíritas reivindicariam um estatuto religioso, todavia, ainda não estariam prontas as condições necessárias para tanto, nem da parte do Estado, nem do espiritismo.
} 
campo denominacional, ou melhor, ofereceriam mais rapidamente aquela referência politicamente tolerável da cultura popular em forma comunitária, denominacional e sedentária, e que seria sobremaneira valorizada como sinal de autenticidade pelos intelectuais das décadas de 1930-1950, pois "macumba", baixos e falsos espiritismos já haviam cumprido seu papel negativo na polarização que demarcaria o campo autêntico para a possessão. E, diante disso, a legitimação denominacional das expressões que, mesmo depois de tudo, ainda permanecessem próximas das matrizes africanas, era a conexão mais difícil. Ao menos sob o ponto de vista do ideal civilizacional propalado, principalmente, pelos segmentos intelectuais intermediários, e a que faltava rumo à conformação de um sentido concorrencial igualitário. Nesse caso, uma das estratégias passaria a de se ser propositivamente formulado na linguagem da tradição e da cultura. Sem essa transformação, não se poderia falar de mercado religioso no Brasil, pois que boa parte das expressões estariam sob atenção de aparelhos garantidores de exceção.

Ao mesmo tempo, seria essa a conexão entre planos distintos, e por vezes discordantes, responsáveis pela própria redefinição que o Estado teria que produzir em sua relação com as religiões e com o significado que se atribuía à liberdade religiosa. De fato, mesmo hoje ainda assistimos a conflitos em que a legitimidade desse ou daquele grupo é questionada. Todavia, a generalização dos meios jurídicos na resolução dos conflitos parece ratificar que o espaço religioso ainda é no Brasil definido por uma garantia de liberdade relativamente sólida por parte do Estado. De qualquer forma, a liberdade religiosa substantiva, a qual parecia uma quimera inaceitável nos anos 19101920, tornar-se-ia uma conquista que contou com a participação simultânea de intelectuais, praticantes e, inadvertidamente, de seus opositores, deixando de ser um princípio formal que demandava exceções, para tornar-se critério a ser respeitado dentro de um consenso mínimo, mas com isso também se contribuía ativamente para o expurgo, dissimulação, ou repressão daquilo que não se quisesse, pudesse ou devesse ser mostrado.

\section{Referências}

AMAR0, Jaqueline de Souza.

(2010). Os combates de Luiz de Mattos (19121924): o espiritismo kardecista e o tratamento médico da doença mental. Dissertação apresentada ao Programa de Pós-graduação em História das Ciências e da Saúde da
Fundação Oswaldo Cruz - FIOCRUZ.

ASAD, Talal.

(2010). A construção da religião como categoria antropológica. Cadernos de Campo, São Paulo, n.19, p.263-284. 
BOURDIEU, Pierre.

(2004). A economia das trocas simbólicas. 5. ed. São Paulo: Perspectiva.

BOYER, Véronique.

(1996). Le don et l'initiation: de l'impact de la littérature sur les cultes de possession au Brésil. L'Homme, 138. p.7-24. Disponivel em: http://www.persee.fr/web/revues/home/ prescript/article/hom_0439-4216_1996_ num_36_138_370072 . Acesso em 10 de setembro de 2013.

BRAGA, Lourenço.

(1953). Umbanda magia branca e Quimbanda magia negra. 9. ed. Rio de Janeiro: Lourenço Braga.

BURKE, Peter.

(2010). Cultura popular na Idade Moderna. Tradução de Denise Bottmann. São Paulo: Companhia das Letras.

CARVALH0, José Murilo de.

(2013). A formação das almas: o imaginário da república no Brasil. São Paulo: Companhia das Letras.

CAMARG0, Cândido Procópio Ferreira.

(1961). Kardecismo e Umbanda: uma interpretação sociológica. São Paulo: Pioneira.

CAPONE, Stefania.

(2009). A busca da África no candomblé: tradição e poder no Brasil. Rio de Janeiro: Contra Capa e Pallas.

COSTA, Flamarion Laba da.

(2002). Onde o Diabo agia na sociedade brasileira segundo a igreja católica na primeira metade do século XX. Guarapuava, Guairacá, n.18, p.41-59. Disponível em: http://www. febnet.org.br/ba/file/Pesquisa/Textos/TCC/ artigocosta.pdf. Acesso em 08 de abril de 2013.

COSTALLAT, Benjamim.

(1990). Os mistérios do Rio. Rio de Janeiro: Biblioteca Carioca, 1990.
EISENSTADT, S. N.

(1969). Modernização: protesto e mudança - modernização de sociedades nacionais. Tradução de José Gurjão Neto. Revisão técnica de Gilberto Velho. Rio de Janeiro: Zahar Editores.

ELIAS, Norbert.

(1997). Os Alemães: a luta pelo poder e a evolução do habitus nos séculos XIX e XX. Rio de Janeiro: Jorge Zahar.

FERNANDES, Florestan.

(2008). A integração do negro na sociedade de classes: volume 1 - ensaio de interpretação sociológica. 5. ed. São Paulo: Globo, 2008.

FERNANDES, Paulo César da Conceição.

(2008). As origens do Espiritismo no Brasil: razão, cultura e resistência no início de uma experiência (1850-1914). Dissertação de mestrado apresentada ao Departamento de Sociologia da Universidade de Brasília - UnB.

GIUMBELLI, Emerson.

(2008). A presença do religioso no espaço público: modalidades no Brasil. Religião e Sociedade, vol.28, n.2. Disponível em http://dx.doi.org/10.1590/S010085872008000200005 . Acesso em janeiro de 2015.

(2003). O "baixo espiritismo" e a história dos cultos mediúnicos. Horizontes antropológicos, v.9, n.19. Disponível em: http://www.scielo.br/scielo.php?pid=S0104$71832003000100011 \&$ script=sci_arttext. Acesso em 27 de janeiro de 2015.

(1997). Heresia, doença, crime ou religião: o Espiritismo no discurso de médicos e cientistas sociais. Revista Antropologia vol.40, n.2. Disponivel em: http://dx.doi.org/10.1590/ S0034-77011997000200002. Acesso em 28 de março de 2012.

GONÇALVES, José Reginaldo dos Santos.

(1996). A retórica da perda: os discursos do patrimônio cultural no Brasil. Rio de Janeiro: UFRJ, 1996. 
HERVIEU-LEGER, Danièle.

(2008). 0 peregrino e o convertido: a religião em movimento. Petrópolis: Vozes.

LEWGOY, Bernardo.

(2008). A transnacionalização do espiritismo kardecista brasileiro: uma discussão inicial. Religião e sociedade vol.28, nº.1. Disponível em: http://dx.doi.org/10.1590/S010085872008000100005 . Acesso em 2 de abril de 2011.

LIMA, Vivaldo da Costa.

(2004). 0 candomblé da Bahia na década de 1930. Estudos Avançados 18 (52). Disponivel em: http://www.scielo.br/ scielo.php?script=sci_arttext\&pid=S010340142004000300014. Acesso em 10 de maio de 2009.

\section{LÜHNING, Ângela.}

(1995-1996). “Acabe com este santo que Pedrito vem aí": mito e realidade da perseguição policial ao candomblé baiano entre 1920 e 1942. Revista USP (28), p.194-220. Disponível em: http://www.usp.br/revistausp/28/14angela.pdf. Acesso em 10 de julho de 2012.

MAGGIE, Yvonne.

(1992). Medo do feitiço: relações entre magia e poder no Brasil. Rio de Janeiro: Imprensa Nacional.

MICELI, Sérgio.

(1979). Intelectuais e classe dirigente no Brasil (1920-1945). São Paulo: DIFEL.

MONTERO, Paula.

(2006). Religião, pluralismo e esfera pública no Brasil. Novos estudos - CEBRAP n.74, março. Disponivel em: http://dx.doi.org/10.1590/ S0101-33002006000100004. Acesso em 5 de junho de 2009.

NEGRÃ0, Lísias Nogueira.

(1996). Entre a cruz e a encruzilhada. São Paulo EDUSP, 1996.

OLIVEIRA, José Henrique Motta de.

(2009). Entre a macumba e o espiritismo: uma análise dos discursos dos intelectuais de umbanda durante o Estado Novo. CAOS -
Revista Eletrônica de Ciências Sociais n.4, p.6085. Disponivel em: http://www.cchla.ufpb. br/caos/n14/3Entre\%20a\%20macumba $\% 20$ e\%200\%20espiritismo.pdf . Acesso em 17 de março de 2012.

ORTIZ, Renato.

(1999). A morte branca do feiticeiro negro: umbanda e sociedade brasileira. São Paulo: Brasiliense.

REIS, João José.

(2008). Domingos Sodré um sacerdote africano: escravidão, liberdade e candomblé na Bahia do século XIX. São Paulo: Companhia das Letras.

RI0, João do.

(1976). As religiões do Rio. Rio de Janeiro: Nova Aguilar, 1976.

SCHWARCZ, Lilia Moritz.

(1993). O espetáculo das raças: cientistas, instituições e questão racial no Brasil 18701930. São Paulo: Companhia das Letras, 1993.

SINGER, Paul.

(1981). Dominação e desigualdade. Estrutura de classes e repartição da renda no Brasil. Rio de Janeiro: Paz e Terra.

SODRÉ, Nelson Werneck.

(1999). História da imprensa no Brasil. 4. ed. Rio de Janeiro: MAUAD Editora, 1999.

SOUZA, Jessé.

(2012). Os batalhadores do Brasil: nova classe média ou nova classe trabalhadora? 2. ed. Belo Horizonte: UFMG.

TAYLOR, Charles.

(2008). Uma era secular. Tradução de Nélio Schneider e Luiza Araújo. São Leopoldo: Unisinos.

WISSENBACH, Maria Cristina Cortez.

(2004). A mercantilização da magia na urbanização de São Paulo, 1910-1940. Revista de História, 150 (1), p.11-39. Disponível em: http://www.revistas.usp.br/revhistoria/ 
article/view/18976. Acesso em 22 de setembro de 2014.

\section{Jornais e Revistas consultados para a composição do artigo}

Na macumba de mãe Elvira: eu, o vereador Clapp e as revelações dos caboclos - figuras históricas - voltando ao consolo da Bahia - notas de Orestes Barbos. 0 Radical, Rio de Janeiro, p.1-2, 31 de maio de 1936.

Jornal do Recife, Recife, p.1, 4 de dezembro de1899.

FRANCO, J. José. O Espiritismo: manual científico e popular, traduzido e anunciado por Carlos de Laet, Rio de Janeiro, Jornal do Brasil, 13 de julho de 1901.

Correio da Manhã, Rio de Janeiro, p. 8, 21 de abril de 1906.

0 BAIXO ESPIRITISMO - DO TRABALHO À LOUCURA - A exploração monetária: o que se deve fazer, Rio de Janeiro, A Época, 23 de dezembro 1918.

0 falso espiritismo - Uma casa de dar fortuna - Faça o que the digo e será feliz - o amor por 150 \$, A Imprensa, Rio de Janeiro, 1 de agosto de 1908.

A Notícia, Salvador, 5 de novembro de 1914.

0 Racionalismo com fatos: desmascarando a falsa ciência dita oficial e o falso espiritismo, dois fabricantes de loucos - $160^{\circ}$ lição - Aos charlatães diplomados, Dr. A. Austregésilo, professor catedrático de clítica neurológica e membro da Academia Brasileira de Letras, e Juliano Moreira. A Razão, Rio de Janeiro. 10 de agosto de 1918.

A Baía, Salvador, 22 de novembro de 1902.

TOLED0, Demétrio de. Segredos - A macumba está em perigo. 0 Malho, Rio de Janeiro, Ano XXXVIII, n. 311, p.41, 18 de maio de 1939.

A Razão, Rio de Janeiro, 14 de janeiro de 1920.
Uma vítima do falso espiritismo: uma fanática que mata o marido à machadinha. A Imprensa, Rio de Janeiro, 18 de julho de 1911.

Quando da bruxaria e do fanatismo. 0 Malho, Rio de Janeiro, 22 de novembro de 1913.

Falando aos habitantes do além túmulo - visitando os 'centros' e observando as 'cavações' e os 'cavadores. A Capital, Salvador, 29 de outubro de1926.

A Capital, Salvador, 29 de outubro de 1926.

A Capital, Salvador, 01 de novembro de 1926.

Macumba na Praça 15, A Manhã, Rio de Janeiro, 28 de agosto de 1926 .

GUIMARÃES, A. Crítica, Rio de Janeiro, 19 de janeiro 1929.

Diário de Notícias, Salvador, 25 de junho de 1912.

0 Malho, Rio de Janeiro, p. 11, 25 de março de 1905.

0 Malho, 19 de maio de 1906.

0 Malho, Rio de Janeiro, 8 de maio 1939.

RAMOS, Arthur. Macumba: religião e ritual dos negros brasileiros. Dom Casmurro, Rio de Janeiro, 25 de maio de1940.

LOUCOS? Um caso estranho occorreu hontem com os moradores de uma casa na rua da Alegria: o resultado das seitas falsas. A Imprensa, Rio de Janeiro, 8 de novembro de 1913.

\section{Recebido em}

janeiro de 2014

\section{Aprovado em}

outubro de 2015 